\title{
The Importance of Locally Embedded Personal Relationships for SME Internationalisation Processes - from Opportunity Recognition to Company Growth
}

\section{Milena Ratajczak-Mrozek*}

\begin{abstract}
The purpose of the paper is to present the importance of locally embedded personal relationships and individuals' networks for the rise of small and medium enterprises (SMEs)' opportunities in the internationalisation process (especially the market entry phase) as well as their international operations and growth. Above all, the aim of the article is to answer the question what is influencing the actual impact of these resulting opportunities on internationalisation and growth.

This paper adopts both a conceptual and empirical approach to the problem based upon a critical review of pertinent literature. Two case studies of companies from industries representing different levels of technological advancement, that is the furniture industry and IT industry, are presented.

The theoretical and empirical analysis presented in the article points to the fact that relationships simultaneously facilitate opportunity recognition and themselves constitute such an opportunity. The analysis carried out as part of the case study proves that main factors determining the rise of the opportunity based on locally embedded personal relationships are trust and mutual understanding, in this way emphasising the importance of relational embeddedness. At the same time the realisation of these opportunities and therefore their impact on the internationalisation process and a company's growth requires additional social factors (an entrepreneurial attitude) as well as economic factors (such as quality and competitive prices).
\end{abstract}

Keywords: relationships, personal relationships, individuals network, local embeddedness, internationalisation, foreign market entry, opportunities, SME.

\footnotetext{
* Milena Ratajczak-Mrozek, PhD, Poznań University of Economics, Department of International Marketing, al. Niepodległości 10,61-875 Poznań, Poland, tel. +48618543312/ fax +48618543610, milena.ratajczak@ue.poznan.pl. The paper was written with the financial support from the Polish National Centre of Science [Narodowe Centrum Nauki] - Decision no. DEC-2012/05/D/HS4/01138. Project "The global and local dimension of business networks" (project leader Milena Ratajczak-Mrozek, PhD).
} 


\section{INTRODUCTION}

Companies' continuing search of new growth possibilities means, in many cases, the necessity to internationalise their activities. Internationalisation is important for companies' development and is related to many positive effects and growth. However, in the case of small and medium enterprises (SMEs) the world is not necessarily truly global. These companies lack among other things the resources required for the execution of large orders and the international reputation necessary to acquire foreign customers which altogether create hindrances for their internationalisation and especially for the initial entry on to a foreign market and the beginning of this process. Thus, from companies' development perspective, it is important to answer a question if and how it is possible to overcome these hindrances And whether, therefore, in the case of SMEs, and especially micro companies traditional approach to planning international activities may be applied (i.e. including formal step-wide planning strategy, foreign market selection input forms, sending offers etc.).

For small and medium companies, an important factor contributing to internationalisation and accompanying growth as well as a solution for the above mentioned hindrances may be the willingness and openness of these SMEs, (their owners and/or managers), to make the most of an opportunity which presents itself. This is related to a more ad hoc internationalisation (ad hoc compared to the outlined strategic approach associated with planning of the next steps of the process). The creation of such international opportunities may be facilitated by personal relationships, analysed in the literature also as individuals' networks or social networks. Their importance is emphasised in the research but mainly international relationships and relationships with foreign customers, intermediaries are underlined. Little attention is paid to the importance of the local origin of these relationships. Meanwhile, the locally embedded relationships with other entities appear also to be important. In this way we may say that the internationalisation process can be explained by the recognition of opportunities that in turn are facilitated by locally embedded personal relationships and the individual's network.

The purpose of the paper is to present the importance of locally embedded personal relationships and individuals' networks for the rise of SMEs' opportunities in the internationalisation process (especially the market entry phase) as well as their international operations and growth. Above all, the aim of the article is to answer the question what is influencing the actual impact of these opportunities on internationalisation and growth. In this way we address the issue of how local and regional factors impact the company 
activities and analyse the role of networks in terms of entrepreneurial opportunity seeking and growth.

This paper adopts both a conceptual and empirical approach to the problem based upon a critical review of pertinent literature. The concepts of opportunities, business networks and personal relationships, as well as embeddedness are applied to the analysis of SMEs internationalisation processes and growth. Additionally two case studies of companies from industries representing different levels of technological advancement, that is the furniture industry and IT industry, are also presented.

The paper is divided into six sections. In the first section a literature review concerning SMEs internationalisation, the essence of international opportunity recognition, and the meaning of personal relationships is presented. In the second section the conceptual framework of the research is proposed. The third section concerns the research method adopted within the empirical analysis. Next, in sections four and five the two aforementioned case studies are presented and discussed. Finally conclusions and directions for further research are presented.

\section{LITERATURE REVIEW}

\section{The specificity of SMEs in terms of internationalisation}

Internationalisation means "the process of increasing involvement in international operations" (Welch and Luostarinen, 1988, p. 36) being mainly an activity driven by the desire to penetrate overseas markets (Fletcher and Barrett, 2001). This traditional approach analyses the entry process and then a company's activities on specific foreign markets.

The main positive effects for companies resulting from internationalisation include enhanced revenues, economies of scale and scope, the efficient utilisation of resources and access to cheaper or scarce resources, foreign know-how, market expansion, adaptive flexibility, diversification of activities and benefits of reputation (Contractor, Kundu and Hsu, 2003; Elango and Sethi, 2007; Barcellos, Cyrino, Oliveira Júnior and Fleury, 2010; Manolova, Manev and Gyoshev, 2010). So these positive effects are to a large extend related to companies' development and growth. Research underlines the positive relationship between internationalisation and a company's performance (Hitt, Hoskisson and Kim, 1997; Gomes and Ramaswamy, 1999; Contractor, 2007; Pangarkar, 2008; Assaf, Josiassen, Ratchford and Barros, 2012). So despite the risks associated with internationalisation (Zaheer, 1995; Barcellos et al., 2010) this process is highly desirable. 
The well-established internalisation theories (the three main theories include the Uppsala model, Dunning's eclectic paradigm and the network approach) were focused on large, multinational companies, whereas international entrepreneurship research began as a response to the "rise in the number of firms that were internationalising while still young and small (McDougall and Oviatt, 2000)" (Ellis, 2011, p. 101). Available research confirms that SMEs have a different specificity in terms of internationalisation processes as they must face more hindrances than large companies. First of all, due to limited internal resources they often lack the resources needed to enter foreign markets (e.g. financial resources or the materials needed for the execution of large orders or the lack of reputation) (Jansson and Sandberg, 2008; Meyer and Skak, 2002; Roberts, 1999). Moreover international activities require a larger proportional allocation of resources of an SME than is the case of a large company. In the case of failure of the particular international activities, "the impact on an SME may be greater, which increases the risk levels of SMEs (Buckley, 1999; Lu and Beamish, 2001)" (Pangarkar, 2008, p. 478). The managerial resources of SMEs and the constraints related to them also have to be taken into consideration. This narrow resource base is not limited solely to production technologies but also to organizational activities (Boter, Holmquist, 1996). Due to constraints of management time, smaller firms might "take short-cuts in decision-making and information gathering" (Buckley, 1999), lacking the information necessary for exploiting any international opportunities (Buckley, 1999, Qian, 2002), managerial expertise and competence (Karagozoglu and Lindell, 1998), comprehensive market research and expert knowledge (Musteen and Datta, 2006).

\section{Opportunity recognition in SMEs internationalisation processes}

Because of the specificity of the functioning of SMEs and the related hindrances and characteristics of their internationalisation process, the approach to internationalisation typical for large companies (i.e. strategic planning, implementation of the next steps) does not necessarily apply. Thus, to overcome the outlined hindrances an important aspect in the SMEs internationalisation process might be seen in the recognition of international opportunities (or international entrepreneurial opportunity recognition) (Chandra, Styles and Wilkinson, 2009).

Within entrepreneurship research, studies of opportunity recognition have been conducted mainly in a domestic (not international) context (Shane, 2000; Arenius and de Clercq, 2005; Ardichvili, Cardozo and Ray, 2003; Eckhardt and Shane, 2003; Ozgen and Baron, 2007). In turn, in the internationalisation research, traditional theories of the internationalisation process (that is the 
Uppsala model, the eclectic paradigm and the network approach) accept the importance of the perception of foreign business opportunities. However, they do not explain or directly address the phenomenon of opportunity recognition and do not explain how these opportunities come to be identified and exploited (Chandra et al., 2009, Ellis, 2011). At the same time a company's internationalisation process may be seen as opportunity driven (Zahra, Korri and Yu, 2005, Johansson and Vahlne, 2009, Ellis 2011). The recognition of an international opportunity is an important element in understanding the internationalisation behavior of companies (Chandra et al., 2009; Ellis, 2011; Johanson and Vahlne, 2009; Oviatt and McDougall, 2005; Zahra et al., 2005) as opportunities are "the most important element of the body of knowledge that drives the process" (Johansson and Vahlne, 2009, p. 1424). The acceptance of this fact has resulted in the growth in the number of studies in this regard (Chandra et al., 2009; Ellis, 2011; Johanson and Vahlne, 2009; Zahra et al., 2005; Kontinen and Ojala, 2011).

Research into opportunity recognition (mainly domestic opportunity recognition) points to two possibilities: opportunity discovery and creation. Opportunity discovery suggests that opportunities in the market are simply being recognised (Kirzner, 1997 Kaish and Gilad, 1991). Opportunity creation assumes that the opportunity is created through a deliberate and systematic search and is realised by one of the companies (Schumpeter, 1934; Herron and Sapienza, 1992). We may agree with the authors who underline that in reality opportunity development includes elements of both discovery and creation (Ardichvili et al., 2003; Johansson and Vahlne, 2009; Chandra et al., 2009). It means that opportunity should not be equated with luck, although it may appear to be luck. Pure luck is "where the finder has done nothing to generate the outcome" (Kirzner, 1997, p. 121). In the internationalisation research it is said that the cases of accidental exporters (Styles and Harcourt, 2001) and "unplanned" internationalisation (Crick and Spence, 2005), are not the examples of luck but "they are examples of the role played by social networks combined with firm competencies and motivations that drive the discovery of international market opportunities" (Chandra et al., 2009, p. 38). For this reason an important area of current research regarding the recognition of international opportunity is the analysis of the reasons that make some companies rather than others first recognise and then exploit opportunities (Acedo and Jones, 2007; Chandra et al., 2009; Ellis, 2011). There are three main drivers of the opportunity recognition process identified in the literature, these are: prior knowledge, international network of contacts and a company's entrepreneurial orientation (meaning autonomy, innovativeness, risk taking, proactiveness and competitive aggressiveness) (Chandra et al., 2009) called also relevant skills and alertness (Kirzner, 1979). Attention is also 
drawn to the fact that "The recognition of exchange opportunities is a highly subjective process, shaped by entrepreneurs' existing ties with others." (Ellis, 2011 , p. 99). That is the reason why personal relationships may be considered as an important trigger of internationalisation.

\section{Personal relationships in the internationalisation processes and opportunity recognition}

Business networks, network relationships and ties between individuals (especially managers or entrepreneurs) are seen as an important resource facilitating internationalisation, especially among SMEs (Crick and Spence, 2005; Hadjikhani, Ghauri and Johanson, 2005; Ellis, 2011; Kontinen and Ojala, 2011).

Interpersonal relationships, also known as individual networks or social networks are known to bring benefits within the internationalisation process in the form of reducing transaction and information-acquisition costs (Peng, Lee and Wang, 2005) (Rutashobya and Jaensson, 2004), risk (Sharma and Blomstermo, 2003) as well as uncertainty (Zain and Ng, 2006) during foreign market entry. They also provide knowledge of new markets (Harris and Wheeler, 2005) and help to develop resources and capabilities needed for internationalisation (Zhu, Hitt and Tihanyi, 2006; Manolova et al., 2010; Chandra et al., 2009). Research suggests that personal relationships offer access to network of relationships in other countries, which can then present the basis of new inter-firm links (Harris and Wheeler, 2005). In this way, personal relationships represent between-firm relationship resources that are fundamental in internationalisation (Ellis, 2011; Harris and Wheeler, 2005).

Personal relationships facilitate the identification of new market opportunities (Manolova et al., 2010; Ellis, 2011; Kontinen and Ojala, 2011; Harris and Wheeler, 2005, Chandra et al., 2009; Crick and Spence, 2005; Komulainen, Mainela and Tahtinen, 2006; Sharma and Blomstermo, 2003). However, most of the literature focuses on the role of international, or cross-border networks and personal relationships. Very few studies focus on relationships within domestic markets and their positive impact on the recognition of international opportunities (exceptions include Manolova et al. (2010)). Meanwhile it may be assumed that locally embedded relationships can be also a source of the aforementioned benefits). Locally embedded relationships mean not only that they originate from local, domestic setting but also that they are based on trust and shared routines. Embeddedness, as a concept rooted in sociology, is the idea that firms are connected by networks of personal relations and economic behavior is embedded in networks of

Learning and Innovation in Space, Arne Isaksen, James Karlsen, Marta Gancarczyk (Eds.) 
interpersonal relations (Granovetter, 1985, Uzzi, 1996). In our study we refer to the breakdown into structural ad relational embeddedness (Granovetter, 1992; Moran, 2005) - "a distinction essentially between the configuration of one's network and the quality of those relationships" (Moran, 2005, p. 1131). We take the view that when defining locally embedded relationships their quality (that is trust and shared norms) is even more important than their structure. In terms of opportunities recognised on local markets, embeddness in a social structure is said to create opportunity and improve performance. "Embedding enables the entrepreneurs to use the specifics of the environment. Thus, both recognition and realisation of opportunity are conditioned by the entrepreneurs' role in the social structure" (Jack and Andersson, 2002, p. 467). It is underlined that this is even more important given that SMEs are embedded in domestic business environments to a greater extent than large multinational enterprises (Meyer and Skak, 2002). However, it is important to analyse the significance of the local embeddedness for the international activities.

\section{RESEARCH FRAMEWORK}

Based on a conducted literature review a research framework was developed that constitutes the starting point for the following case studies analysis (see Figure 1).

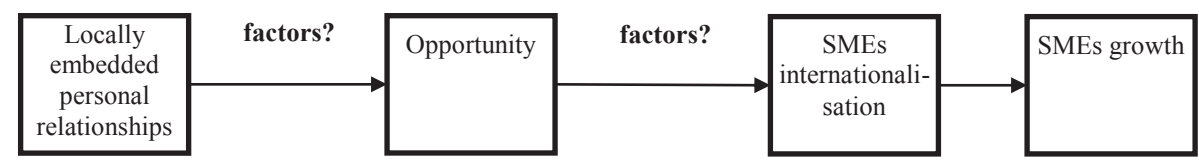

Figure 1. The process of transferring personal relationships in to SMEs internationalisation and growth - research framework

It is assumed that locally embedded relationships (established with different types of entities) contribute to the emergence of opportunity and then to the SMEs' internationalisation and their growth.

In this article we focus on the company's entry to the foreign market. Hence, the direct impact of personal relationships on company's growth (different then related to internationalisation) and the impact of these relationships on company's international activities after entering the foreign market are not tested. These assumptions are conditioned by the necessity to put the analysis at a specific moment of time. 
The two important questions that are analysed are:

- what are the main factors determining the rise of opportunity based on personal relationships,

- what are the main determinants influencing the actual impact of these resulting opportunities on SMEs internationalisation and growth

Additionally the supplementary questions are asked which then result in the course of the conducted study:

- what is the specificity of the analysed SMEs internationalisation process and especially hindrances of this process,

- what kind of growth and development the analysed companies achieved due to internationalisation and their first foreign market entry.

\section{RESEARCH METHOD}

The theoretical analysis presented in the article is exemplified with two case studies. Both analysed companies while being small/ micro enterprises operating only in the domestic market have acquired a large and important foreign customer, thus starting their internationalisation process. Companies selected for the case studies represent industries with different levels of technological advancement, i.e. furniture industry and IT industry. The two case studies may be seen as both comparative and complementary. The same research questions used for analysis indicate the comparativeness and using the two industries representing different levels of technological advancement implies the complementarity.

The two case studies offer the chance to see and compare different aspects of the analysed phenomenon. The furniture industry, classified as a lowtechnology, is characterised by a high degree of embedding in local resources but also a large extent of internationalisation ( $98 \%$ of Polish production was exported in 2011 (http://stat.gov.pl/)). In turn the IT industry is classified as high-technology knowledge intensive services. The high-technology companies are said to be forced to be active on international scale because the domestic market creates somewhat limited demand for their products/services which have to be quickly commercialised (Madsen and Servais, 1997; Spence, 2003; Ratajczak-Mrozek, 2012). However high-technology knowledge intensive companies located in Poland do not impress both in terms of turnover and production (both 9th place in the European Union in 2010) and the level of exports (14th in the EU in 2011) (Figueira and Skaliotis, 2013).

Data for the case studies was collected using semi-structured, in-depth, face-to-face and phone/Skype interviews (Silverman, 2000; Punch, 2005). a purposive sample was applied. Altogether 13 in-depth interviews were conducted. In the case of the furniture industry, 6 detailed interviews were 
carried out with company owners as well as with 2 owners of companies identified as being key suppliers. In the case of the IT industry, 4 detailed interviews were carried out with the CEO of an IT company in Poland as well as 1 with the COO of the company's important client. In the case of both focal firms, additional contacts were made in order to obtain supplementary detailed information and in order to clarify doubts. The high positions held by the representatives of these firms ensured that they possessed the appropriate level of knowledge regarding topics covered by the research.

The interviews, which were carried out during the period January-October 2014 , were conducted by two trained interviewers, which aimed to ensure an objective assessment of the information obtained. The interviews were based mainly on open-ended and probing questions to encourage discussion of the phenomena (Denzin and Lincoln, 1998). The questions regarding the process of internationalisation, company's development and the identification and description of important customers, suppliers and other entities were asked. Crucial from the perspective of the article was an answer to the question "how the company managed to acquire such a large and important foreign customer." The interviews were recorded and transcribed, thereby creating an interview protocol. In order to ensure objectivism and triangulation of the data interpretation (Gummesson, 2001) two researchers worked independently on the codification and analysis of the transcripts in order to assess the importance and strength of the relationship. Their analyses were compared and in the case of any inconsistencies, a third researcher was requested to assess the materials. Additionally, all of the companies' representatives had the possibility to verify the transcripts of their interviews. All significant comments regarding the transcript were incorporated into the data analysis.

The case studies adopt the perspective of two focal companies, however, verified using information obtained from the remaining entities. Unless otherwise noted the presented statements were presented by particular case focal company's representatives (furniture company - two owners, IT company - CEO). Both case studies are presented in the same order determined by the research framework.

\section{ANALYSIS- EVIDENCE FROM TWO INDUSTRIES}

\section{Furniture company}

The Company Flow (Furniture Luxury of Wood; the name of the company was changed at its request), located in Poland with $100 \%$ of Polish capital, designs and produces furniture (mainly wardrobes, kitchen furniture, office 
furniture and bathroom furniture). This small company that employs less than 49 people, was founded in 2004. In 2013 the company had between 200-250 customers (both from B2B and B2C sector).

In the year 2011 Flow initiated the process of internationalising its operations, i.e. acquired a foreign customer - a large Scandinavian company operating in the recreational industry. This Scandinavian Customer is the company's only foreign customer. It mainly purchases wardrobes and in 2013 generated approximately $60 \%$ of the Flow's sales.

Thanks to the cooperation with the Scandinavian Customer, Flow was able to expand and, what is more, the cooperation "forces" a lot of innovation in the production process, the purchase of new machinery and means of transportation (which are both currently used to produce and provide services also for other customers). So acquiring a foreign customer meant not only company's growth and internationalisation but also actual business development. In terms of growth there is also further potential internationalisation to be achieved as in the near future, the customer will possibly enter a new market in a new country which will mean that Flow will also expand its operations into the new country.

How did the company attract such an important foreign customer and start its internationalisation process? As one of the Owners describes the process: "Someone whom we know very well did some other work for this company. He said that he knew a company which produces furniture well. They asked us for the first production" Contact with the Danish customer was developed thanks to personal relationships on the local market and the word-of-mouth referral.

At the beginning of Flow's internationalisation process one more personal relationship built with one of local suppliers was particularly important: "when we received the first orders from the foreign customer, (...) we weren't able to purchase the required materials for cash. We went to the supplier, sat down, talked a while and the trust they placed in us means that we are still cooperating to this day." Since then this domestic wholesaler is classified as an important supplier for Flow due to the financial support he provided in the form of a trade credit. Without this relationship, Flow would not have been able to develop and specifically acquire the resources for product development.

What is also important is that the Owners underline the hindrance of the internationalisation process from the position of a SME which is the lack of international reputation. In such case: "who would read the offer we submitted to them?". 


\section{IT company}

The IT micro-company Gridia was funded and began operating on the Polish market in 2006. The company started by offering basic IT services and later gradually started to transform in to a software development company.

In 2008 this IT company started its internationalisation process by cooperating with Scandinavian customers, including nSense Group where it was subcontracted to carry out outsourced IT development. The nSense Group is a highly specialised IT security company offering high-end security services to Northern Europe but also to the USA and the Philippines. After confirming the high quality of services for nSense Group which were also low cost, there was a gradual expansion of the profile of the orders as well as an increase in trust between companies. Finally in 2010, there was a decision to create nSense Poland S.A. which became a new entity in the nSense Group structure. That meant that the Polish IT company had to formally cease trading but in practice: "we created a new company called nSense Poland S.A. where everyone, including the employees, was transferred and so in reality this was a continuation albeit not legally". The Polish branch does not have a marketing department, nor engage in final customer acquisition. It exports all of its services to other companies forming the nSense Group (although end-beneficiaries of these services are Group's end-customers). In fact nSense Poland is right now a centre for knowledge and know-how of the Group, which only confirms company's development and growth.

How did the company attract such an important customer, who at the end transformed into a partner in the same multinational company? As the CEO of the IT company describes the process: in 2008 also through personal relationships "we were able to acquire our first customer, a Polish branch of a Danish company (...). Then we became friendly with one of the company's managers who proposed that perhaps we could do something together. After a while he left that company and became our partner." The partner had knowledge of the Danish IT market and "was a Danish resident and had contacts there." because of the local contacts, his role of the partner was to acquire customers and generate business. This Danish partner acquired nSense as a customer. In terms of the beginning of the internationalisation process the CEO of in that time micro IT company (that is from 2006 to 2008, before acquiring foreign customer) underlines that the company was not able to deliver its assumed growth strategy: "No large companies wanted to talk to us because we were only a two-person company". 


\section{DISCUSSION}

The two case studies, although they apply to different industries (lowtechnology production furniture industry and high-technology knowledge intensive IT industry) point to many similarities in terms of embarking on an internationalisation process through SMEs' as well as their growth.

Firstly, regardless of the industry and its key resources determining competitive advantage, the most significant hindrance for initiating the internationalisation process is the lack of reputation. In the case of small, unknown firms, traditional strategic initiatives such as market research or the submission of offers to potential foreign customers often do not provide results. Due to the lack of a reputation and the resulting difficulty in making an impact as well as a higher risk for potential customers, such offers from unknown companies are often not taken into account when choosing a supplier.

The next barrier, albeit consciously referred to here secondly, are the limited resources of small companies. However, this is more important in the case of production firms (e.g. furniture production) where significant, specific material resources are required in order to deliver an order for a foreign customer, as opposed to a knowledge-intensive company (e.g. IT) where human resources and the specialist knowledge they possess are more important. The cases of the companies described, however, point to the fact that lack of resources for growth and development can be circumvented through the engagement in relationships at the local level (i.e. by being locally embedded). In the case of the furniture company, meetings with a local supplier, the development of trust and a good relationship allowed the company to obtain the resources required in order to deliver an order for the foreign customer and to thereby make the most of an opportunity which had presented itself.

Both of the case studies identified that locally embedded personal relationships are key for international opportunity emergence. Moreover these relationships, which are important in terms of growth, may be locally embedded personal relationships. In the case of the furniture company, the acquisition of the foreign customer was helped by the fact that the company obtained a recommendation from a contact. This recommendation was not in the form of a letter of reference or a set of references provided together with a proposal, but a personal recommendation provided by a contact who was asked to comment on the company. Moreover, this process was supported by the other locally embedded relationship, which has developed with the local supplier. In the case of the IT company, the acquisition of nSense as a foreign customer was both a strategic step as well as an example of an opportunity. The parties met in Poland whilst working on a local project and the mutual 
understanding between them meant that a personal relationship was formed and which was subsequently transformed in to a business relationship. Without meeting on the local market whilst working on a project with a local customer (albeit foreign owned) the relationship with nSense, an important foreign supplier, would not have been developed. Based upon these examples, it can be concluded that locally embedded relationships simultaneously both facilitate and constitute opportunity recognition. The main factors determining the rise of opportunity based on personal relationship underlined by both companies' representatives are trust and mutual understanding, which apparently may be related to the idea of relational embeddedness.

Locally embedded relationships constitute a certain bridgehead facilitating opportunity recognition. Thanks to relationships, it is possible to break through the barrier of a lack of an international reputation. They allow for first contact. However, in order to be able to utilise an opportunity, owners must adopt the correct attitude, the willingness to take a risk and to be open. At the point at which an opportunity is taken, economic factors come into play, which include competitive prices as well as a high level of professionalism and service quality. In the case of the furniture company it was the timely completion of high quality cheaper furniture. In the case of the IT company it was access to cheaper, highly qualified specialists, a significant growth factor due to the size of the Scandinavian market which is characterised by a limited supply of this type of labour. In every case these are therefore economic factors which are significant for a given industry.

Thanks to the contacts with foreign customers and thus entering into foreign markets, companies gained not only revenue growth (or in the case of a production company the growth of the machinery park), but also reached the development in terms of innovation (furniture company) and knowledge (IT company) which is highly desirable.

\section{CONCLUSIONS}

SMEs wishing to develop and striving for growth must often demonstrate a more ad hoc approach to internationalisation focused on exploitation of the opportunities. The theoretical and empirical analysis presented in the article points to the fact that relationships simultaneously facilitate opportunity recognition and themselves constitute such an opportunity. Moreover, research into internationalisation usually concentrates on the importance of relationships with foreign counterparts. Meanwhile, the analysis carried out as part of the case study proved that locally embedded personal relationships can play a key role in the creation of international opportunities and the internationalisation process, especially in its initial 
phase. What is more, these do not have to be relationships with customers but also may be relationships with other persons or entities (e.g. suppliers). These relationships are particularly important in the case of lack of reputation or resources necessary for internationalisation. Research carried out in an article has shown that main factors determining the rise of the opportunity based on personal relationships are trust and mutual understanding, in this way emphasising the importance of relational embeddedness.

The realisation of the emerging opportunities and therefore their impact on the internationalisation process and a company's growth requires additional factors which were identified in the case studies. These include social factors which are represented by an entrepreneurial attitude as well as economic factors (such as quality and competitive prices). Locally embedded relationships constitute a bridgehead facilitating opportunity recognition. Social factors are key for utilising opportunities which present themselves, namely the appropriate attitude on behalf of owners and managers (e.g. the willingness to take a risk or to be open) and then when the opportunity is being developed, economic factors come in to play which include competitive prices as well as the high level of professionalism and service quality.

The aforementioned dependencies are presented in Figure 2. What is important from the perspective of the analysis carried out in the article is that described dependencies were confirmed in the case of two completely different SMEs - a production company and a company based on non-material assets i.e. knowledge.

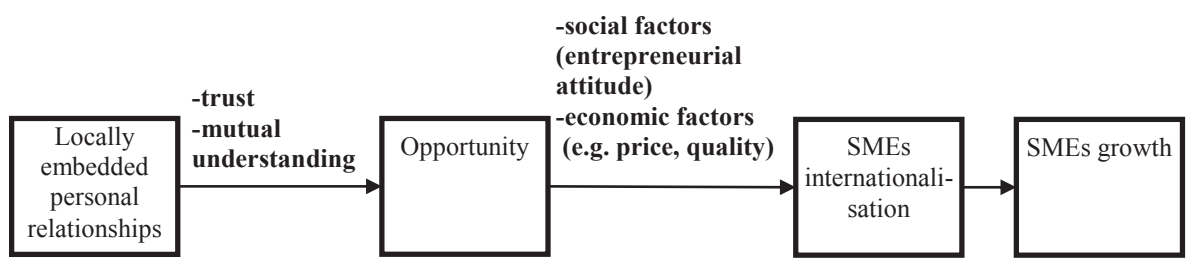

Figure 2. The process of transferring personal relationships into SMEs internationalisation and growth - conclusions

Whilst discussing issues relating to the utilisation of opportunities in the internationalisation and growth processes of companies, the following statement made by the COO of the nSense Group is therefore significant: "in all entrepreneurial companies there is an element of a surprise and an element of just a coincidence". Are the described situations therefore only a case of luck? To a certain degree yes, if meeting certain people. can be 
called luck. However, this is the only element of coincidence and luck. The development of a positive impression and opinion on the local market as well as the development of trust within local relationships demands both specific entrepreneurial characteristics facilitating the utilisation of a given opportunity as well as the skill of being able to build economic factors significant for a given industry (the timely completion or orders, product quality, the specialist knowledge possessed by human resources, price). Without these elements, coincidence and the element of luck in the form of the development of the appropriate personal relationships would not develop into a long-term business relationship leading to the internationalisation, growth and development of SMEs. However, there is the need to consciously create network relationships both at the individual and company level. It is in fact the network of contacts as well as a positive opinion which can result in the appearance of an opportunity allowing an SME to overcome hindrances in the internationalisation process.

The presented research is not free from some limitations which simultaneously indicate future directions of research. First of all, it would be advisable to carry out wider research which would facilitate a comparison of the importance of locally and foreign embedded relationships. This would be possible by carrying out studies among a larger number of cases as well as through a quantitative analysis. Above all, a detailed analysis of relationships as well as the interdependencies between factors (i.e. entrepreneurship and economic factors) would be also valuable.

\section{References}

Acedo, F. J., Jones, M. V. (2007). Speed of internationalization and entrepreneurial cognition: Insights and a comparison between international new ventures, exporters and domestic firms. Journal of World Business, 42(3), 236-252.

Ardichvili, A., Cardozo, R., Ray, S. (2003). a theory of entrepreneurial opportunity recognition and development. Journal of Business Venturing, 18(1), 105-123.

Arenius, P. de Clercq, D. (2005). a network-based approach on opportunity recognition. Small Business Economics, 24(3), 249-65.

Assaf, A. G., Josiassen, A., Ratchford, B. T, Barros, C. P. (2012). Internationalization and Performance of Retail Firms: a Bayesian Dynamic Model. Journal of Retailing, 88(2), 191-205.

Barcellos, E. P., Cyrino, Á. B., Oliveira Júnior, M. d. M., Fleury, M. T. L. (2010). Does Internationalization Pay off? a Study of the Perceived Benefits and Financial Performance of the International Operations of Brazilian Companies. GCG: Revista de Globalización, Competitividad \& Gobernabilidad, 4(3), 38-61. 
Boter, H., Holmquist, C. (1996). Industry characteristics and internationalization processes in small firms. Journal of Business Venturing, 11(6), 471-487.

Buckley, P. J. (1999). Foreign direct investment by small and medium sized enterprises: The theoretical background. In: P. J. Buckley, P. N. Ghauri (Eds.), The internationalization of the firm (pp. 1999-2010). NY: International Thomson Business Press.

Chandra, Y., Styles, C., Wilkinson, I. (2009). The recognition of first time international entrepreneurial opportunities: Evidence from firms in knowledge-based industries. International Marketing Review, 26(1), 3061.

Contractor, F. J. (2007). Is International Business Good for Companies? The Evolutionary or Multi-Stage Theory of Internationalization vs. Transaction Costs Perspective. Management International Review, 47(3), 453-475.

Contractor, F., Kundu, S., Hsu, C. C. (2003). a Three-Stage Theory of International Expansion: The Link between Multinationality and Performance in the Service Sector. Journal of International Business Studies, 34(1), 5-18.

Crick, D., Spence, M. (2005). The internationalization of high performing UK high-tech SMEs: a study of planned and unplanned strategies. International Business Review, 14(2), 167-185.

Denzin, N. K., Lincoln, Y. S. (Eds.) (1998), Strategies of qualitative inquiry, California, USA: Sage Publications Inc.

Eckhardt, J. T., Shane, S. A. (2003). Opportunities and entrepreneurship. Journal of Management, 29(3), 333-349.

Elango, B., Sethi, S. P. (2007). An exploration of the relationship between country of origin (COE) and the internationalization-performance paradigm. Management International Review, 47(3), 369-392.

Ellis P. D., (2011). Social ties and international entrepreneurship: Opportunities and constraints affecting firm internationalization. Journal of International Business Studies, 42, 99-127.

Figueira M. H., Skaliotis M (Eds.) (2013). Science, technology and innovation in Europe 2013 edition. Retrieved from http://epp.eurostat.ec.europa. eu/cache/ITY_OFFPUB/KS-GN-13-001/EN/KS-GN-13-001-EN.PDF.

Fletcher, R., Barrett, N. (2001). Embeddedness and the Evolution of Global Networks. An Australian Case Study. Industrial Marketing Management, 30(7), 561-573.

Gomes, L., Ramaswamy, K. (1999). An empirical examination of the form of the relationship between multinationality and performance. Journal of International Business Studies, 30(1), 173-88.

Granovetter, M. (1985). On the Embeddedness of Social Life. American Journal of Sociology, 91, 481-493.

Granovetter, M. (1992). Problems of explanation in economic sociology. In: N. Nohria, R. G. Eccles (Eds.), Networks and Organizations (pp. 25-56). Boston: Harvard Business School Press.

Gummesson, E. (2000). Qualitative methods in management research, Sage Publications International. 
Hadjikhani, A., Ghauri, P., Johanson, J. (2005). Introduction: Opportunity development in business networks. In: P. Ghauri, A. Hadjikhani, J. Johanson (Eds.), Managing opportunity development in business networks (pp. 1-24). New York: Palgrave.

Harris, S., Wheeler, C. (2005). Entrepreneurs' relationships for internationalization: functions, origins and strategies. International Business Review, 14(2), 187-207.

Herron, L., Sapienza, H. J. (1992). The entrepreneur and the initiation of new venture launch activities. Entrepreneurship Theory and Practice, 17(1), 49-55.

Hitt, M. A., Hoskisson, R. E., Kim, H. (1997). International Diversification: Effects on Innovation and Firm Performance in Product-Diversified Firms. Academy of Management Journal, 40(4), 767-79.

Jack, S. L., Anderson, A. R. (2002). The effects of embeddedness on the entrepreneurial process. Journal of Business Venturing, 17(5), 467-487.

Jansson, H., Sandberg, S. (2008). Internationalization of small and medium sized enterprises in the Baltic Sea Region. Journal of International Management, 14(1), 65-77.

Johanson, J., Vahlne, J.-E. (2009). The Uppsala internationalization process model revisited: From liability of foreignness to liability of outsidership. Journal of International Business Studies, 40, 1411-1431.

Kaish, S., Gilad, B. (1991). Characteristics of opportunities search of entrepreneurs versus executives: sources, interests, and general alertness. Journal of Business Venturing, 6(1), 45-61.

Karagozoglu, N., Lindell, M. (1998). Internationalization of small and medium sized technology based firms: An exploratory study. Journal of Small Business Management, 36(1), 44-59.

Kirzner, I. M. (1997). Entrepreneurial discovery and the competitive market process: An Austrian approach. Journal of Economic Literature, 35(1), 6085.

Kontinen, T., Ojala, A. (2011). Network ties in the international opportunity recognition of family SMEs. International Business Review, 20(4), 440453.

Komulainen, H., Mainela, T., Tahtinen, J. (2006). Social networks in the initiation of a high-tech firm's internationalization. International Journal of Entrepreneurship and Innovation Management, 6(6), 526-541.

Lu, J. W., Beamish, P. W. (2001). The internationalization and performance of SMEs. Strategic Management Journal, 22(6/7), 565-584.

Madsen, T. K., Servais, P. (1997). The internationalization of born globals: an evolutionary process?. International Business Review, 6(6), 561-583.

Manolova, T. S., Manev, I. M., Gyoshev, B. S. (2010). In good company: The role of personal and inter-firm networks for new-venture, internationalization in a transition economy. Journal of World Business, 45(3), 257-265. 
McDougall, P. P., Oviatt, B. M. (2000). International entrepreneurship: The intersection of two research paths. Academy of Management Journal, 43(5), 902-906.

Meyer, K., Skak, A. (2002). Networks, serendipity and SME entry into Eastern Europe. European Management Journal, 2(2), 179-188.

Moran, P. (2005). Structural vs. relational embeddedness: social capital and managerial performance. Strategic Management Journal, 26(12), 11291151.

Musteen, M., Datta, D. K. (2010). The influence of international networks on internationalization speed and performance: a study of Czech SMEs. Journal of World Business, 45(3), 197-205.

Ozgen, E., Baron, R. A. (2007). Social sources of information in opportunity recognition: Effects of mentors, industry networks, and professional forums. Journal of Business Venturing, 22(2), 174-192.

Pangarkar, N. (2008). Internationalization and performance of small- and medium-sized enterprises. Journal of World Business, 43(4), 475-485.

Peng, M.W., Lee, S.-H., Wang, D. Y. L. (2005). What determines the scope of the firm over time: a focus on institutional relatedness. Academy of Management Review, 30(3), 622-633.

Punch, K., (2005). Introduction to social research. Quantitative and qualitative approaches, London: Sage.

Ratajczak-Mrozek, M. (2012). Global Business Networks and Cooperation within Supply Chain as a Strategy for High-Tech Companies' Growth. Journal of Entrepreneurship, Management and Innovation, 8(1), 35-51.

Roberts, J. (1999). The Internationalisation of Business Service Firms: a Stages Approach. Service Industries Journal, 19(4), 68-88.

Rutashobya, L., Jaensson, J. E. (2004). Small firms' internationalization for development in Tanzania: Exploring the network phenomenon. International Journal of Social Economics, 31(1/2), 159-172.

Qian, G. (2002). Multinationality, product diversification and profitability of emerging US small and medium sized enterprises. Journal of Business Venturing, 17(6), 611-633.

Schumpeter, J.A. (1934). The theory of economic development. Cambridge, MA: Harvard University Press.

Shane, S. (2000). Prior knowledge and the discovery of entrepreneurial opportunities. Organization Science, 11(4), 448-69.

Sharma, D., Blomstermo, A. (2003). The internationalization process of Born Globals: a network view. International Business Review, 12(6), 739-753.

Silverman, D. (2000). Doing qualitative research: a practical handbook, London: Sage.

Spence, M. (2003). International Strategy Formation in Small Canadian HighTechnology Companies - a Case Study Approach. Journal of International Entrepreneurship, 1(3), 277-296. 
Styles, C., Seymour, R. (2006). Opportunities for marketing researchers in international entrepreneurship. International Marketing Review, 23(2), $126-45$.

Uzzi, B. (1997). Social Structure and Competition in Interfirm Networks: The Paradox of Embeddedness. Administrative Science Quarterly, 42(1), 3567.

Welch, L. S., Luostarinen, R. K. (1988). Internationalisation: Evolution of a Concept. Journal of General Management, 2, 36-64.

Zaheer, S., (1995), Overcoming the liability of foreignness. Academy of Management Journal, 38(2), 341-363.

Zahra, S. A., Korri, J. S., Yu, J. F. (2005). Cognition and international entrepreneurship: Implications for research on international opportunity recognition and exploitation. International Business Review, 14(2), 129146.

Zain, M., Ng, S. I. (2006). The impacts of network relationships on SMEs' internationalization process. Thunderbird International Business Review, 48(2), 183-205.

Zhu, H., Hitt, M. A., Tihanyi, L. (2006). The internationalization of SMEs in emerging economies: Institutional embeddedness and absorptive capacities. Journal of Small Business Strategy, 17(2), 1-26.

\begin{abstract}
Abstrakt (in Polish)
Celem artykułu jest przedstawienie znaczenia lokalnie osadzonych relacji personalnych dla pojawienia się okazji dla małych i średnich przedsiębiorstw (MSP) w procesie ich internacjonalizacji (a szczególnie w fazie wejścia na rynek zagraniczny) oraz wzrostu. Ponadto celem artykułu jest identyfikacja czynników warunkujqcych rzeczywiste wykorzystanie i przełożenie tak powstałej okazji na internacjonalizację i wzrost przedsiębiorstw.

W artykule zastosowano zarówno podejście koncepcyjne jak i empiryczne do analizy problemu bazujqc na krytycznej analizie literatury przedmiotu. Przedstawiono również dwa studia przypadków przedsiębiorstw reprezentujq̨cych dwie branże o różnym poziomie zaawansowania technologicznego, tj. branżę meblarskq i branżę IT.

Przedstawiona $w$ artykule analiza teoretyczna i empiryczna wykazała, że relacje jednocześnie umożliwiajq rozpoznanie okazji jak i same stanowiq takq okazję. Przeprowadzona analiza studiów przypadków dowiodła, że głównymi czynnikami majqcymi wpływ na przełożenie relacji personalnych na pojawienie się okazji sq zaufanie i wzajemne zrozumienie, podkreślając tym samym znaczenie osadzenia relacyjnego. Przy czym trzeba podkreślić, że tak jak te relacje wspomagajq tworzenie okazji, tak już dla ich zrealizowania i przełożenia na internacjonalizację $i$ wzrost przedsiębiorstwa, niezbędne sq dodatkowe zidentyfikowane $w$ przedstawionych badaniach czynniki w postaci czynników społecznych reprezentowanych przez postawę przedsiębiorczq oraz czynników ekonomicznych (takich jak jakość i konkurencyjne ceny).
\end{abstract}

Journal of Entrepreneurship Management and Innovation (JEMI), Volume 10, Issue 3, 2014: 89-108 
Słowa kluczowe: relacje, relacji personalne, lokalne osadzenie, internacjonalizacja, wejście na rynek zagraniczny, okazje, MSP.

\section{Biographical note}

Milena Ratajczak-Mrozek is an Assistant Professor in the Department of International Marketing at the Poznań University of Economics. She is the scholarship holder of Minister of Science and Higher Education (scholarship for outstanding young scientists) and author of over 60 publications. She has conducted research projects for both science and business (in the field of cooperation, innovativeness and foreign activity). Her main areas of research include the analysis of companies' relationships and cooperation in international setting as well as competitive advantage in the global market. She is a member of a few international scientific organizations: The European International Business Academy (EIBA), The European Marketing Academy (EMAC) and an international research group Industrial Marketing and Purchasing Group. 